\title{
STRATEGI PENINGKATAN KINERJA APARATUR PEMERINTAH DAERAH PASCA PEMINDAHAN IBU KOTA (STUDI KASUS PADA SEKRETARIAT DAERAH KABUPATEN BOLAANG MONGONDOW PROVINSI SULAWESI UTARA)
}

Oleh

\author{
Reza Adi Sucipto Damopolii ${ }^{1}$, \\ Ermaya Suradinata², Irawan $^{3}$ \\ 1) Pemerintah Kabupaten Bolaang Mongondow \\ Program Magister Terapan Studi Pemerintahan Daerah Institut Pemerintahan Dalam Negeri \\ rezaadisucipto17@gmail.com \\ 2,3) Institut Pemerintahan Dalam Negeri
}

\begin{abstract}
$T$ This research is about analisys and formulation strategies to increase aparatus performance after the removal of the Capital City of Bolaang Mongondow Regency. The research method used by researchers is descriptive research and exploratory research with a qualitative approach. Collecting data through observations, interviews, documentation, as well as audio and visual material. Data analysis techniques were performed by data reduction, data presentation, and drawing conclusions developed by Miles and Hubermas. In determining the strategy for improving performance of the Bolaang Mongoandow district government apparatus, researchers used ASOCA (Ability, Strength, Opportunities, Culture, and Agility) analysis. cultural elements in this strategy make it suitable with the characteristics of the Indonesian nation in which various cultures grow and develop. The results of the research which are based on five dimensions, namely the quantity of work, quality of work, timeliness, attendance and the ability to work together show that the performance of local government officials after the relocation of the capital city has experienced a significant degradation. reward and punishment, incentives, the distance between the residence of the apparatus and the district capital, internal control and supervision, leadership, and work standards that have not been fully used as a reference in working. The strategies formulated to improve the performance of apparatus in this study are the maximum application of information technology, advanced education for ASN, strict enforcement of discipline, use of flats for ASN residences, assessment for all ASN, information technology training, building a reward system through giving bonus (bonus pay) for outstanding civil servants, building governance 4.0, commitment to improving performance, building cohesiveness and a work ethic based on the cultural wisdom of local communities that uphold mutual improvement (mototabian) and love each other (mototabian) framed with mutual respect (mooaheran)) and polite language (mobobahahasan).
\end{abstract}

Keywords: capiltal city, performance, apparatus, strategy

\section{AbSRAK}

$\mathrm{P}_{\mathrm{p}}^{\mathrm{e}}$ enelitian ini merupakan sebuah studi kasus yang mengkaji kinerja aparatatur di Sekretariat Daerah serta merumuskan strategi Pemerintah Kabupaten Bolaang Mongondow dalam 
meningkatkan kinerja aparatur pemerintah daerah pasca pemindahan Ibu Kota. Metode penelitian yang digunakan peneliti yaitu penelitian deskripsi dan penelitian eksploratif dengan pendekatan kualitatif. Pengumpulan data melalui obervasi, wawancara, dokumentasi, serta audio dan visual meterial. Teknik analisis data dilakukan dengan reduksi data, penyajian data, dan penarikan kesimpulan yang dikembangkan oleh Miles dan Hubermas. Penentuan Strategi peningkatan kinerja aparatur pemerintah Kabupaten Bolaang Mongondow pasca pemindahan ibu kota peneliti menggunakan analisis ASOCA (ability, strength, opportunities, culture, dan agility). Masuknya unsur budaya dalam strategi inilah yang membuatnya cocok dengan karakteristik Bangsa Indonesia yang didalamnya tumbuh dan berkembang beragam budaya. Hasil penelitian yang didasarkan pada lima dimensi yakni kuantitas pekerjaan, kualitas pekerjaan, ketepatan waktu, kehadiran dan kemampuan kerja sama menunjukan bahwa kinerja aparatur pemerintah daerah pasca pemindahan ibu kota mengalami degradasi yang cukup signifikan, beberapa faktor yang mempengaruhi adalah fasilitas kerja, lingkungan kerja, sistem reward and punishment, insentif, jarak tempat tinggal aparatur dengan ibu kota kabupaten, pengendalian dan pengawasan internal, kepemimpinan, serta standar kerja yang belum secara penuh dijadikan sebagai acuan dalam berkerja. Adapun strategi yang terumuskan untuk meningkatkan kinerja aparatur dalam penelitian ini adalah penerapan teknologi informasi secara maksimal, pendidikan lanjutan bagi ASN, penegakan disiplin secara ketat, pemanfaatan rumah susun untuk tempat tinggal ASN, Asessment bagi seluruh ASN, pelatihan teknologi informasi, membangun reward system melalui pemberian bonus (bonus pay) bagi ASN berprestasi, membangun tata kelola pemerintahan 4.0, komitmen peningkatan kinerja, membangun kekompakan dan etos kerja berdasarkan kearifan budaya masyarakat lokal yang menjunjung sikap saling memperbaiki (mototompiaan) dan saling menyayangi (mototabian) dibingkai dengan sikap saling menghormati (mooaheran) dan bahasa yang santun (mobobahasaan).

Kata kunci: ibu kota, kinerja, aparatur, strategi

\section{PENDAHULUAN}

$\mathrm{K}^{\mathrm{s}}$ abupaten Bolang Mongondow merupakan salah satu daerah otonom di Provinsi Sulawesi Utara yang telah dimekarkan, pemekaran tersebut melahirkan empat kabupaten dan satu kota sebagai daerah otonom baru (DOB). Pada 2007 lahir DOB Kota Kotamobagu dan DOB Kabupaten Bolaang Mongondow Utara, satu tahun berselang yaitu pada 2008 kembali lahir DOB Kabupaten Bolaang Mongondow Timur dan DOB Kabupaten Bolaang Mongondow Selatan.

Sebagai implikasi dari pemekaran daerah tersebut, Ibu Kota Kabupaten Bolaang Mongondow yang semula berlokasi di wilayah Kotamobagu, harus pindah ke wilayah yuridiksi atau ke cakupan wilayahnya. Setelah melakukan proses pengkajian dan penelaahan maka dipilihlah Kecamatan Lolak sebagai lokasi ibu kota yang baru. Legalitas pemindahan Ibu Kota tersebut ditetapkan dengan Peraturan Pemerintah Nomor 9 Tahun 2010 tentang Pemindahan Ibu Kota dari wilayah Kota Kotamobagu ke wilayah Kecamatan Lolak Kabupaten Bolaang Mongondow Provinsi Sulawesi Utara. Setelah mendapatkan tututan dari masyarakat Bolaang Mongondow agar ibu kota segera dipindahkan, realisasi pemindahan ibu kota tersebut dapat dilaksanakan pada 11 Agustus 2011.

Suatu harapan besar terkandung dalam semangat pemindahan ibu kota tersebut, yaitu tata kelola penyelenggaraan pemerintahan daerah, termasuk didalamnya pelayanan publik, pembangunan dan pemberdayaan masyarakat akan semakin baik. Namun dalam realitasnya menunjukkan hal yang kontra produktif, penyelenggaraan 
Tabel 1 Hasil Evaluasi Kinerja Penyelenggaraan Pemerintahan Daerah (EKPPD) Pemerintah Kabupaten Bolaangmongondow 2010-2017

\begin{tabular}{cccccl}
\hline No & Tahun & $\begin{array}{c}\text { Pering- } \\
\text { Kat }\end{array}$ & Skor & Status & Ket. \\
\hline 1. & 2010 & 251 & 2.25 & Tinggi & Kepmendagri No. 100-297 Th. 2012 \\
2. & 2011 & 359 & 1.51 & Sedang & Kepmendagri No. 120-2818 Th. 2013 \\
3. & 2012 & 362 & 0.82 & Rendah & Kepmendagri No. 120-251 Th. 2014 \\
4. & 2013 & 377 & 0.69 & Rendah & Kepmendagri No. 120-4761 Th. 2014 \\
5. & 2014 & 388 & 0.98 & Rendah & Kepmendagri No. 800-35 Th. 2016 \\
6. & 2015 & 368 & 1.58 & Sedang & Kepmendagri No. 120-10421 Th. 2016 \\
7. & 2016 & 357 & 2.47 & Tinggi & Kepmendagri No. 100-53 Th. 2018 \\
8. & 2017 & 388 & 1.59 & Sedang & Kepmendagri No. 118-8840 Th. 2018 \\
\hline
\end{tabular}

Sumber: www.otda.kemendagri.go.id

pemerintahan daerah di Kabupaten Bolaang Mongondow semakin mengalami degradasi setelah pemindahan Ibu Kota.

Hal tersebut dibuktikan dengan hasil penilaian dan audit terhadap Pemerintah Kabupaten Bolaang Mongondow sebagai berikut: Pertama, dari Evaluasi Kinerja Penyelenggaraan Pemerintahan Daerah (EKPPD) yang secara rutin dilaksanakan oleh Kementarian Dalam Negeri, hasilnya menunjukkan terjadinya fluktuasi dalam hal kinerja penyelenggaraan pemerintahan daerah Kabupaten Bolaang Mongondow terlebih pada tahun 2011 sampai dengan tahun 2015 terjadi penurunan yang cukup signifikan. Sebagaimana yang tersaji pada tabel 1 di atas
Kedua, berkenaan dengan pengelolaan keuangan daerah, Pemerintah Kabupaten Bolaang Mongondow kembali memperoleh Disclaimer of Opinion (Tidak Menyatakan Pendapat) dari BPK RI atas pemeriksaan laporan keuangan pemerintah daerah tahun 2018, dua tahun sebelumnya yakni pada pemeriksaan atas Laporan Keuangan Pemerintah Daareh Tahun 2016 dan Tahun 2017 juga memperoleh opini Disclaimer of Opinion (Tidak Menyatakan Pendapat), ini merupakan "hat trick" opini TMP terhadap Pemerintah Kabupaten Bolaang Mongondow. Opini terhadap pemeriksaan Laporan Keuangan Pemerintah Daerah Kabupaten Bolaang Mongondow dapat dilihat pada tabel 2.

Tabel 2 Opini BPK RI terhadap Hasil Pemeriksaan Laporan Keuangan Pemerintah Kabupaten Bolaangmongondow Tahun 2012-2018

\begin{tabular}{lllllll}
\hline \multicolumn{1}{c}{$\mathbf{2 0 1 2}$} & $\mathbf{2 0 1 3}$ & \multicolumn{2}{c}{$\mathbf{2 0 1 4}$} & \multicolumn{2}{c}{$\mathbf{2 0 1 5}$} & \multicolumn{2}{c}{$\mathbf{2 0 1 6}$} & \multicolumn{2}{c}{$\mathbf{2 0 1 7}$} & $\mathbf{2 0 1 8}$ \\
\hline Tidak & & Wajar & Wajar & Tidak & Tidak & Tidak \\
Menyatakan & Tidak Wajar & Dengan & Dengan & Menyatakan & Menyatakan & Menyatakan \\
Pendapat & (Adverse & Pengecualian & Pengecualian & Pendapat & Pendapat & Pendapat \\
(Disclaimer of & Opinion) & (Qualified & (Qualified & (Disclaimer of & (Disclaimer of & (Disclaimer of \\
Opinion) & & Opinion) & Opinion) & Opinion) & Opinion) & Opinion) \\
\hline
\end{tabular}

Sumber: BPK Perwakilan Provinsi Sulawesi Utara 
Tabel 3 Realisasi Pengelolaan Keuangan Kabupaten Bolaangmongondow Tahun 2012-2016

\begin{tabular}{|l|l|c|c|c|c|c|}
\hline \multirow{2}{*}{ No } & \multicolumn{1}{|c|}{ Uraian } & \multicolumn{5}{|c|}{ Realisasi Tahun (Rp) } \\
\cline { 3 - 7 } & & $\mathbf{2 0 1 2}$ & $\mathbf{2 0 1 3}$ & $\mathbf{2 0 1 4}$ & $\mathbf{2 0 1 5}$ & \multicolumn{1}{c|}{$\mathbf{2 0 1 6}$} \\
\hline 1. & Pendapatan & $538,610,736,426$ & $599,168,080,265$ & $677,232,334,672$ & $809,358,151,745$ & $925,585,663,950$ \\
\hline 2. & Belanja & $528,626,466,585$ & $583,240,227,294$ & $668,160,063,705$ & $823,968,657,331$ & $953,193,868,708$ \\
\hline 3. & $\begin{array}{l}\text { Pen e ri ma a n } \\
\text { Pembiayaan }\end{array}$ & 45.338 .583 .750 & 54.786 .761 .240 & 68.810 .924 .211 & 76.883 .195 .178 & 58.278 .829 .291 \\
\hline 4. & $\begin{array}{l}\text { Pengeluaran } \\
\text { Pembiayaan }\end{array}$ & 536.092 .351 .00 & 2.000 .000 .000 & 1.000 .000 .000 & 4.000 .000 .000 & 33.912 .372 .400 \\
\hline
\end{tabular}

Sumber: Badan Keuangan Daerah Kabupaten Bolaangmongondow, Tahun 2017

Ketiga, dalam hal pelayanan publik, Ombudsman Republik Indonesia merilis hasil penilaian terhadap pelayanan publik di Kabupaten Bolaang Mongondow tahun 2018, Kabupaten Bolaang Mongondow memperoleh status "zona kuning" atau zona sedang dalam kepatuhan terhadap standar pelayanan publik (www.ombudsman.go.id).

Fenomena tersebut jika ditilik lebih dalam berbanding terbalik dengan ABPD Kabupaten Bolaang Mongondow yang terus meningkat setiap tahunnya. Peningkatan anggaran belanja seharusnya juga meningkatkan kualitas kinerja penyelenggaraan pemerintahan daerah. Peningakatan APBD dapat dilihat pada tabel 3.

Kondisi Kinerja Pemerintah Kabupaten Bolang Mongondow tersebut jika tidak dilakukan langkah-langkah preventif dan mitigatif dapat mengakibatkan menunurnya kepercayaan publik terhadap pemerintah daerah, dan tentunya akan berdampak pada penyelenggaraan program-program pemerintah daerah. Hal itulah yang menimbulkan kegelisahan dan menjadi dasar bagi peneliti untuk melakukan penelitian, dengan asumsi bahwa Dengan asumsi bahwa kinerja aparatur pemerintah daerah sangat memenentukan keberhasilan dalam penyelenggaraan pemerintahan daerah.

Hasil penelusuran lebih lanjut, peneliti menemukan beberapa masalah yang menyertai, yaitu kinerja aparatur pemerintah daerah dinilai mengalami penurunan, tingkat akuntabilitas kinerja instansi pemerintah Kabupaten Bolaang Mongondow cenderung stagnan dari tahun ke tahun, menurunya tingkat kedisiplinan aparatur pemerintah daerah di Kabupaten Bolaang Mongondow pasca pemindahan ibu kota, minimnya sarana dan prasarana pendukung, kurangnya pengawasan dan pengendalian internal secara prosedural terhadap aparatur sipil negara Kabupaten Bolaang Mongondow.

\section{Tujuan Penelitian}

1. Untuk mengetahui dan menganalisis bagaimana kinerja aparatur pemerintah daerah pasca pemindahan Ibu Kota di Kabupaten Bolaang Mongondow.

2. Untuk mengetahui dan menganalisis apa yang menjadi pendukung dan penghambat peningkatan kinerja aparatur pemerintah daerah pasca pemindahan ibu kota.

3. Untuk mengetahui dan menganalisis strategi peningkatan kinerja aparatur pemerintah daerah pasca pemindahan ibu kota di Kabupaten Bolaang Mongondow.

\section{KAJIAN PUSTAKA}

\section{Konsep Kinerja}

Kinerja berasal dari Bahasa Inggris yaitu "performance", The Oxford English 
Dictionary defines performance as the accomplishment, execution, carrying out, working out of anything ordered or undertaken (kinerja didefinisikan sebagai prestasi, pelaksanaan dan penyelesaian apapun yang diperintahkan dan dilakukan), sedangkan The Scribner Bantam English Dictionary (1979) menyebutkan bahwa, performance berakar pada kata "to perform" yang artinya 1) to do carry out, execute (melakukan, menjalankan, melaksanakan; 2) to discharge of fulfill; as vow (memenuhi atau menjalankan kewajiban yang diniatkan); 3) to execute an undertaking (melaksanakan atau menyempurnakan tanggung jawab); 4) to do what is expected of a person (melakukan sesuatu yang diharapkan seseorang).

Mencermati apa yang didefinisikan oleh The OxfordEnglish Dictionary dan TheScribner Bantam English Dictionary, "to perform" merupakan kata yang menggambarkan adanya aktivitas/kegiatan, dalam Kamus Besar Bahasa Indonesia disebutkan kinerja adalah "sesuatu yang dicapai, prestasi yang diperlihatkan, kemampuan kerja (tentang peralatan), dari definisi etimologis dan definisi sinonim dari kata kinerja bisa dikatakan kinerja memiliki makna yang luas, karena tidak sebatas berbicara tentang hasil kerja (output) tapi berbicara juga bagaimana proses kinerja, atau rangkaian kegiatan yang dilakukan seseorang atau kelompok.

Kinerja merupakan suatu hal yang penting dalam setiap organisasi, termasuk juga organisasi publik. OECD (Organization For Economic Co-Operation And Development) memberikan jawaban mengapa kinerja itu sangat penting (why is performance so important?) terlebih pada organisasi publik, karena:

"The citizen's expectations of good service and of value for tax money have increased. Citizens are more knowledgeable, and access to information laws and policies have increased citizen's access to information and their expectations of government transparency. Consequently, the performance, effectiveness and efficiency of the public administration have become more key concerns for governments" (OECD, 2008:46)

Pemahaman penulis terhadap kutipanitu adalah karena adanya harapan masyarakat bahwa pemerintah telah meningkatkan pelayanan yang baik dan telah memberikan peningkatan nilai manfaat dari uang pajak yang dipungut terhadapnya. Masyarakat ingin memiliki kemampuan lebih dalam mengakses informasi mengenai peningkatan pelaksanaan kebijakan-kebijakan. Konsekuensinya kinerja, efektifitas dan efisiensi harus menjadi konsern bagi pemerintah.

Beranjak dari deskripsi dan analisis kritis terhadap konsep teori yang dikemukakan sebelumnya, dapat tarik pemahaman tentang konsep kinerja yaitu merupakan performa aparatur atau sekelompok aparatur dalam suatu instansi menjalankan serangkaian aktivitas sesuai dengan wewenang, tugas dan tanggung jawab profesionalnya dengan mendayagunakan segala potensi yang dimiliki dalam upaya pencapaian tujuan secara legal, tidak melanggar hukum, dan tidak bertentangan dengan moral atau etika demi memberikan hasil dan manfaat (output dan outcome) bagi organisasi, kinerja juga merupakan bagian yang sangat penting dalam organisasi karena kinerja dapat menentukan keberhasilan dan kesuksesan organisasi dalam mencapai tujuannya.

\section{Dimensi Kinerja}

Dimensi kinerja merupakan aspekaspek yang dijadikan sebagai acuan dalam megukur kinerja, kemudian dari dimensi itu ditetapkan inikator yang sifatnya merinci dimensi-dimensi tersebut. Dari penelusuran penulis terhadap literatur terlihat perbedaan-perbedaan dimensi dan indikator yang kemukakan oleh para ahli. Beberapa dimensi dan indikator perlu ditelaah, sehingga diperoleh dimensi mana 
yang relevan dengan masalah penelitian. Berikut adalah beberapa dimensi kinerja yang dikemukakan oleh para ahli beserta penelaahannya.

Penulis menemukan beberapa dimensi kinerja yang dikemukakan oleh Mitchell dan Larson, yang disebutnya sebagai area of performance, yakni 1) Quality of Work (Kualitas Kerja) 2) Promptness (Ketepatan) 3) Initiative (Prakarsa) 4) Capability (Kemampuan) dan 5) Communication (Komunikasi). (Mitchell R. Terence, 1987 : 491).

Dalam penelitian ini, penulis mengacu pada teori kinerja yang dikembangkan oleh Bangun sebagai alat untuk mengukur kinerja aparatur pemerintah daerah, alasan penulis memilih teori ini karena teori Bangun dinilai relevan dengan masalah yang penulis teliti, dikemukakannya:

"Untuk memudahkan penilaian terhadap kinerja karyawan, standar pekerjaan harus dapat diukur dan dipahami secara jelas. Suatu pekerjaan dapat diukur melalui jumlah, kualitas, ketepatan, waktu pengerjaannya, kehadiran, kemampuan bekerja sama yang dituntut suatu pekerjaan tertentu. (Bagun Wilson, 2006:233-234).

Adapun uraian dari kelima dimensi tersebut adalah sebagai berikut.

1. Jumlah Pekerjaan/Kuantitas Pekerjaan

Menunjukan jumlah pekerjaan yang dilakukan oleh individu atau kelompok sebagai persyaratan yang menjadi standar pekerjaan. Setiap pekerjaan memiliki persyaratan yang berbeda, sehingga dibutuhkan karyawan yang memenuhi persyaratan tersebut baik pengetahuan, keterampilan, dan kemampuan yang mempuni. Juga dengan adanya persyaratan tersebut dapat diketahui jumlah aparatur yang dibutuhkan untuk dapat mengerjakannya.

\section{Kualitas Pekerjaan}

Berbicara tentang kualitas (quality) yang ditekankan adalah pada baik atau buruknya suatu yang dihasilkan, sering kali ditemui dalam suatu pekerjaan terpenuhi dari segi jumlah tetapi tidak memenuhi kriteria yang diinginkan atau tergolong buruk, seringkali juga ditemui segi jumlah yang dihasilkan sedikit tetapi semuanya memenuhi standar yang diinginkan atau tergolong baik. Disebutkan Bangun bahwa setiap pekerjaan mempunyai standar kualitas tertentu yang harus disesuaikan oleh karyawan untuk mengerjakannya sesuai ketentuan. Karyawan/ aparatur memiliki kerja baik bila dapat menghasilkan pekerjaan sesuai persyaratan kualitas yang dituntut oleh pekerjaan tersebut (Bangun Wilson, 2012: 23).

3. Ketepatan Waktu

Ketepatan berasal dari kata "tepat" dalam Kamus Besar Bahasa Indonesia diartikan sebagai 1) betul atau lurus (arah, jurusan); berbetulan benar, 2) kena benar (pada sasaran, tujuan, maksud, dan sebagainya), 3) tidak ada selisih sedikit pun; tidak kurang dan tidak lebih; persis, 4) betul atau cocok (tentang dugaan, ramalan, dan sebagainya), 5) jitu (tentang tindakan, aturan, kritik, dan sebagainya), 6) betul atau mengena tentang perkataan, jawaban, dan sebagainya.

4. Kehadiran

Kinerja aparatur juga ditentukan oleh kehadiran aparatur ditempat kerja, pekerjaan menuntut kehadiran aparatur sesuai dengan waktu yang telah ditentukan. Beberapa tipe pekerjaan mememerlukan kehadiran aparatur selama 8 jam sehari dan 5 hari kerja dalam seminggu. 
5. Kemampuan kerja sama

Beberapa pekerjaan tidak dapat diselesaikan oleh satu orang saja, bahkan sebagian besar pekerjaan memerlukan kerja sama antar aparatur, artinya harus diselesaikan oleh dua orang atau lebih. Oleh karena itu kerja sama menjadi penting dan selalu dibutuhkan.

\section{Strategi}

Secara etimologi kata strategi berasal dari bahasa Yunani Klasik "stategio" (jenderal) yang pada dasarnya diambil dari kata "pasukan" atau "memimpin". Bracker dalam Heene et al. mengatakan penggunaan kata kerja Yunani yang berhubungan dengan "stategio" ini dapat diartikan sebagai "perencanaan dan pemusnahan musuhmusuh dengan menggunakan cara yang efektif berdasarkan sarana-sarana yang dimiliki (Heene Aimi et al., 2010:53).

Menurut Bryson, strategi biasanya dikembangkan untuk mengatasi isu strategis, strategi menjelaskan respon organisasi terhadap pilihan kebijakan pokok (Bryson M. Jhon, 2008:189). Sedangkan isu strategis adalah sebagai masalah yang diperbincangkan, dapat pula merupakan persoalan kebijakan fundamental yang dapat mempengaruhi organisasi dan manajemen. Strategi menunjukkan pada program tindakan keputusan atau alokasi sumber daya yang mendefinisikan bagaimana organisasi itu, apa yang dikerjakan organisasi dan mengapa organisasi melakukannya.

Strategi dalam organisasi sudah seharusnya dan sepantasnya tidak bertentangan dengan nilai yang hidup dalam masyarakat, karena organisasi terutama organisasi publik bergerak di lingkungan masyarakat. Oleh sebab itu penting untuk menyesuaikan dengan norma-norma yang hidup dan diakui oleh masyarakat. Ketika melakukan tindakan yang bertentangan dengan norma-norma itu maka organisasi akan mengalami kesulitan. Strategi juga sebaiknya menjawab respon-respon terhadap tuntutan-tuntutan masyarakat dan apa yang menjadi kepentingan (interest) masyarakat.

Salah satu konsep strategi yang sesuai dengan nilai-nilai masyarakat Indonesia adalah strategi ASOCA yang merupakan singkatan dari (Ability, Strength, Opportunities, Culture, and Agility) (Suradinata Ermaya, 2014 : 18). Masuknya unsur budaya dalam strategi inilah yang membuatnya cocok dengan karakteristik bangsa Indonesia yang didalamnya tumbuh dan berkembang beragam budaya.

\section{HASIL DAN PEMBAHASAN}

Dalam bagian ini peneliti akan menganalisis data yang diperoleh dilapangan, data yang diperoleh berupa hasil observasi atau pengamatan terhadap objek penelitian, wawancara dengan narasumber kunci, group discussion, serta dokumentasi-dokumentasi yang berkaitan dengan kinerja aparatur pemerintah daerah. Semua data akan diolah dengan metode kualitatif deskriptif.

\section{Kuantitas Kerja}

Keterbatasan fasilitas penunjang masih kurang memadai juga dari segi kuantitas beberapa sub bagian kekurangan tenaga pelaksana/staf. Oleh karena itu dapat dikatakan bahwa pencapaian target masih rendah dikarenakan belum adanya penyampaian target yang harus dicapai dan masih kurangnya pemahaman aparatur ditingkat pelaksana terhadap dokumendokumen perencanaan, dan masih terbatasnya fasilitas penunjang serta masih terbatasnya kuantitas aparatur di beberapa sub bagian.

Sebagaimana telah diungkapkan oleh para ahli bahwa kurangnya pemahaman berkenaan dengan kompetensi atau kapasitas dari aparatur, rendahnya kapasitas aparatur dalam sebuah organisasi akan menghambat pecapaian target kerja. Sedangkan Fasilitas 
kerja berkenaan dengan sarana fisik untuk mempermudah pekerjaan dari aparatur, kekurangan fasilitas kerja tentu dapat menghambat pelaksanaan pekerjaan seharihari.

\section{Kualitas Kerja}

Berdasar pada hasil pengamatan dan wawancara yang dilakukan, peneliti mendapatkan suatu pemaknaan bahwa proses kerja yang dilakukan di Sekretariat Daerah selama ini belum menjadikan standar operasional pekerjaan sebagai acuan dalam pelaksanaan pekerjaan, hanya menjalankan rutinitas pekerjaan yang telah menjadi tradisi di unit kerja masing-masing, oleh karenanya tertib pelaksanaan pekerjaan belum dapat dibangun oleh Apararatur di Sekretariat Daerah Kabupaten Bolaang Mongondow.

Jika pekerjaan diselesaikan lebih cepat atau sama dengan waktu dari waktu yang telah ditentukan tentu tidak akan menjadi masalah, yang menjadi masalah kemudian adalah pelaksanaan pekerjaan melebihi waktu yang telah ditetapkan dan tanpa ada komunikasi dengan pihak yang berkepentingan.

Berdasarkan pada paparan di atas dapatlah dimaknai bahwa pelaksanaan pekerjaan sesuai dengan prosedur masih rendah dikarenakan SOP yang hanya dijadikan sebagai penggugur kewajiban, SOP ada tetapi tidak dijadikan acuan dalam pelaksanaan pekerjaan.

Selanjutnya berkaitan dengan hasil kerja, untuk mengetahui hasil kerja aparatur Pemerintah di Sekretariat Daerah Kabupaten Bolaang Mongondow penelusurannya lebih difokuskan pada wawancara dengan pegawai eksternal Sekretariat Daerah. Hal ini bertujuan untuk menemukan jawaban yang lebih objektif dibandingkan dengan yang pegawai internal Sekretariat Dearah itu sendiri.

Selain itu, disampaikan juga oleh beberapa kepala-kepala bagian bahwa peralatan sebagai penunjang pekerjaan masih belum memadai, dikatakan oleh Kepala Bagian Organisasi bahwa untuk pengadaan fasilitas penunjang pekerajaan masih di fokuskan pada bagian yang baru terbentuk dan membutuhkan fasilitas yang canggih yaitu Bagian Unit Layanan Pengadaan, yang tentunya bergelut dengan lelang proyek pemerintah daerah.

Berdasarkan analisa terhadap kualitas kerja aparatur pemerintah daerah di Sekretariat Daerah yang dipaparkan di atas dapat diketahui mengapa kinerja aparatur masih rendah karena beberapa hal yaitu, SOP yang telah dibuat oleh semua bagian di Sekretariat Daerah hanya tersimpan di dalam komputer dan belum dijadikan sebagai acuan dalam pelaksanaan pekerjaan. Kemudian berkaitan dengan masih rendahnya kualitas aparatur terutama dalam hal penggunaan komputer, dan masih kurangnya fasilitas penunjang pekerjaan.

\section{Ketepatan Waktu}

Berdasarkan pada pengamatan dan hasil wawancara yang dilakukan oleh peneliti dapat ditarik pemahaman yang kemudian menjadi jawaban mengapa ketepatan waktu kerja aparatur pemerintah daerah di Sekretariat Daerah masih rendah karena: 1) adanya kebiasaan pemborosan waktu kerja pada hal-hal yang tidak berkaitan dengan pekerjaan, seperti masih berlamalama di kantin setelah jam istrirahat selesai, 2) adanya sikap bersama-sama jalan ke kantin, dan jika salah satu dari rombongan masih berada di kantin yang lain juga ikut belum beranjak dari tempat makan, 3) adanya keinginan untuk segera pulang ke Kotamobagu tempat dimana ASN di Sekretariat Daerah berdomisili.

\section{Kehadiran}

Beranjak dari hasil pengamatan dan wawacara serta penelaahan terhadap dokumen-dokumen yang berkaitan 
dengan kehadiran pegawai dapat dipahami mengapa kehadiran aparatur Pemerintah di Sekretariat daerah masih rendah pasca pemindahan ibu kota, beberapa hal yang menjadi penyebapnya. Terlebih dahulu dipahami bahwa kehadiran aparatur menjadi hal yang paling merosot pasca ibu kota dipindahkan, penyebapnya mulai dari keterbatasan sarana angkutan bagi ASN yang tinggal di Kotamobagu, rendahnya insentif yang diterima, lingkungan kerja yang masih kurang nyaman bagi ASN terutama bagi mereka ditingkat pelaksana/staf, belum adanya tindakan tegas bagi aparatur yang sering kali kedapatan tidak tepat waktu, sering tidak berada diruangan saat jam kerja dan masih kurangnya pengawasn dan pengendalian internal di Sekretariat Daerah Kabupaten Bolaang Mongondow.

\section{Kemampuan Kerja Sama}

Dari pengamatan dan wawancara yang dilakukan, peneliti dapat menemukan suatu pemaknaan bahwa darisisi kemampuan kerja sama aparatur Pemerintah di Sekretariat Daerah ini masih bisa terbilang cukup baik, ketika satu unit membutuhkan bantuan tenaga sub bagian lain berserta dengan stafnya turu serta membantu menyelesaikan pekerjaannya terutama pekerjaan berat yang sifatnya temporer, sedangkan untuk rasa saling menghargai antar sesama rekan kerja pada umumnya telah terbentuk, hanya ada beberapa saja yang masih kurang mengerti arti dari profersionalisme kerja dan hirarkis dalam organisasi.

\section{Faktor Pendukung dan Penghambat}

Peningkatan kinerja aparatur pemerinth di Sekretariat Daerah Kabupaten Bolaang Mongondow pasca pemindahan Ibu Kota dipengaruhi oleh faktor yang mendukung peningkatan kinerja maupun faktor yang menghambat peningkatan kinerja, berikut akan penulis uraikan faktor pendukung dan penghambat peningkatan kinerja Aparatur Pemerintah Sekretariat Daerah Kabupaten
Bolang Mongondow pasca pemindahan Ibu Kota.

Berdasarkan pada hasil pengamatan dan wawancara peneliti dengan Kepala Bagian Organsasi, Kepala Bagian Tata Usaha Pimpnan, Kepala Bagian Hukum dan Ham, Kepala Bagian Pemerintahan, Kasubag Analisis Formasi Jabatan, Kasubag Akuntabilitas dan Pemberdayaan Aparatur diperoleh informasi mengenai hal-hal yang mendukung Peningkatan Kinerja Aparatur Pemerintah di Sekretariat Daerah Kabupaten Bolaang Mongondow pasca pemindahan ibu kota :

a. Adanya Komitmen Pimpinan untuk meningkatkan Kinerja ASN

b. Lahirnya Undang-Undang Nomor 5 Tahun 2014 tentang ASN berserta tutunan-turunannya.

c. Tesedianya kesempatan pendidikan lanjutan bagi ASN dari berbagai intansi publik atau swasta.

d. Telah tersedianya Sarana Angkutan Bagi ASN yang Tinggal di Kotamobagu

e. Tersedianya rumah susun bagi ASN

f. Adanya Program Pengolahan Data yang memadai untuk pengelolaan surat di Sekretariat Daerah Kabupaten Bolaang Mongondow;

g. Adanya penerapan teknologi informasi pada tatanan manajemen pemerintahan di Kabupaten Bolaang Mongondow;

Berdasarkan pada hasil pengamatan dan wawancara peneliti dengan Kepala Bagian Organsasi, Kepala Bagian Tata Usaha Pimpnan, Kepala Bagian Hukum dan HAM, Kepala Bagian Pemerintahan, Kasubag Analisis Formasi Jabatan, Kasbag Akuntabilitas dan Pemberdayaan Aparatur diperoleh informasi mengenai hal-hal yang menghambat Peningkatan Kinerja Aparatur Pemerintah di Sekretariat Daerah Kabupaten Bolaang Mongondow pasca pemindahan ibu kota: 
a. Masih minimnya fasilitas penunjang pekerjaan di hampir semua bagian di Sekretariat Daerah;

b. Belum maksimalnya pengendalian dan pengawasan internal bagi aparatuur dan tindakan tegas bagi aparatur yang melanggar ketentuan disiplin;

c. Belum adanya reward and punishment system

d. Minimnya TPP bagi ASN dan masih minumnya insentif bagi THL

e. Faktor jarak tempat tinggal ASN

f. Kondisi lingkungan kerja yang kurang nyaman (uncomfortable) bagi Aparatur Pemerintah di Sekretariat Daerah.

g. Standar Operasional Prosedur yang belum dijadikan acuan dalam pelaksanaan pekerjaan.

\section{Strategi Peningkatan Kinerja Aparatur Pemerintah Sekretariat Daerah Kabupaten Bolaang Mongondow}

Penentuan strategi dalam rangka peningkatan kinerja aparatur pemerintah daerah di Sekretariat Daerah Kabupaten Bolaang Mongondow pasca pemindahan ibu kota peneliti menggunakan analisis ASOCA yang merupakan singkatan dari (Ability, Strength, Opportunities, Culture, and Agility) sebagaimana yang telah dikemukakan pada BAB sebelumnya. Untuk mengetahui unsurunsur yang terdapat dalam anlisis ini peneliti menggunakan metode ekploratif, dalam arti peneliti sendiri melakukan penggalian secara luas terhadap segala yang berkaitan dengan unsur-unsur ASOCA.

ASOCA terbagi dalam dua bagian yaitu faktor internal yaitu 1) Ability, 2) Strength, 3) Agility dan faktor eksternal yaitu 1) Opportunities, 2) Culture.

\section{Analisis Faktor Internal}

1. Ability (Kemampuan)

Tersedianya SDM yang mampu mengembangkan penerapan teknologi informasi di Sekretariat Daerah Kabupaten Bolaang Mongondow; Mampu menyelesaikan pekerjaan dengan anggaran yang terbatas; Mampu berkerja dalam kondisi dibawah tekanan; Mampu mensiasati berbagai tantangan pekerjaan yang dihadapi; Mampu menyesuaikan dan menjalankan suatu hal baru dalam organisasi.

2. Strength (Kekuatan)

Adanya komitmen yang kuat dari unsur pimpinan saat ini dan seluruh aparatur pemerintah daerah di Sekretariat Daerah untuk meingkatkan kinerja; Adanya Program Pengolahan Data yang memadai untuk pengelolaan surat di Sekretariat Daerah Kabupaten Bolaang Mongondow; Adanya penerapan teknologi informasi pada tatanan manajemen pemerintahan di Kabupaten Bolaang Mongondow.

3. Agility (Kecerdasan)

Adanya kekompakan dalam hal mewujudkan kebaikan bersama; ASN Setda dapat mengambil panutan dari unsur-unsur pimpinan; Dapat menerima keadaan terburuk tanpa disertai dengan sikap emosi dan anarkis; Mampu berinovasi dalam menghadapi tantangan pekerjaan;

\section{Analisis Faktor Eksternal}

1. Oportunities (Peluang)

Adapun peluang-peluang yang dimiliki oleh Aparatur Pemerintah di Sekretariat Daerah dalam meningkatkan kinerja adalah sebagai berikut: tersedianya dua unit rumah susun kapasitas 120 kamar bagi ASN yang sampai saat ini belum ada ASN yang menempatinya; Tersedianya program pendidikan lanjutan bagi ASN dari berbagai institusi publik ataupun swasta dalam maupun luar negeri; Lahirnya Undang-Undang ASN bersereta turunannya yang merupakan babak baru manajemen ASN; Terbukanya peluang 
pelaksanaan program asessment bagi seluruh ASN; Telah terbangun infrasturktur teknologi di Ibu Kota baru Kabupaten Bolaang Mongondow;

2. Culture (Budaya)

Adanya Moto Leluhur Bolaang Mongondow yakni Mototompiaan (saling memperbaiki), Mototabian (saling menyayangi) dan Mototanoban (saling mengingatkan); Adanya-nilai luhur masyarakat Mongondow yang disebut Mooaheran (tahu menempatkan diri), Mobobahasaan (menyampaikan sesuatu dengan tata bahasa yang halus), Mobobangkalan (menghormati orang yang lebih tua); Indispliner telah membudaya dikalangan ASN Setda yaitu tidak datang tepat waktu, tidak memenuhi jam kerja, tidak berada di Kantor saat jam kerja.

\section{Pilihan Strategi}

Beranjak dari rumusan analisis ASOCA di atas, telah diperoleh sebelas rumusan strategi yang dapat digunakan dalam meningkatkan kinerja aparatur pemerintah di Sekreatariat Daerah Kabupaten Bolaang Mongondow. Kesebelas rumusan strategi tersebut selanjutnya akan dilakukan penilaian untuk menentukan bobot nilai dari masing-masing rumusan strategi.

Dalam menentukan bobot nilai dari rumusan strategi tersebut peneliti penggunakan perhitungan Litmust Test yang dikembangkan oleh Bryson. Perhitungan Litmust Test kemudian akan diperoleh skor (nilai) dari masing-masing rumusan strategi, nilai rumusan langkah strategis yang paling tinggi adalah rumusan yang benar-benar strategis, sedangkan rumusan langkah strategis dengan nilai terendah adalah rumusan yang bersifat operational.

1) Mencanangkan penggunaan teknologi informasi dalam setiap pekerjaan (sangat strategis);
2) Mendorong ASN Sekretariat Daerah yang berpestasi untuk mengikuti program pendidikan lanjutan (strategis);

3) Penegakan disiplin kerja melalui penerapan UU ASN beserta turunannya secara tegas (sangat strategis);

4) Menanfaatkan rumah susun dengan mewajibkan seluruh Pejabat Eselon II, III, dan IV di Sekretariat Daerah untuk menempati rumah susun dan berada di Ibu Kota Kabupaten (sangat strategis);

5) Menysusun Program Asessment Center bagi seluruh aparatur Pemerintah di Sekretariat Daerah Kabupaten Bolaang Mongondow (sangat strategis);

6) Membuat program pelatihan penggunaan teknologi informasi bagi seluruh ASN di Sekretariat Daerah Kabupaten Bolaang Mongondow terutama pelatihan komputer dan pengunaan aplikasi (sangat strategis);

7) Menempatkan ASN Sekretariat Daerah sesuai dengan hasil asessment center (sangat strategis);

8) Membangun reward system dengan pemberian bonus (bonus pay) bagi ASN Sekretariat Daerah yang mampu berprestasi dan/atau mampu berinovasi (sangat strategis);

9) Menerapkan tata kelola pemerintahan 4.0 secara bertahap dan berkesinambungan dalam rangka mewujudkan pemerintahan yang baik dan bersih/good governance (strategis);

10) Mencanangkan komitmen peningkatan kinerja bagi seluruh ASN Sekreatariat Deerah Kabupaten Bolaang Mongondow dengan berasas pada profesionalitas, proporsionalitas, efektif dan efisien (operational);

11) Membangun kekompakan dalam hal kedisiplinan dan etos kerja dengan semangat Mototompiaan (saling memperbaiki), Mototanoban (saling mengingatkan) dibingkai dengan bahasa 
yang baik dan sopan (Mobobahasaan) dan tahu menempatkan diri (Mooaheran) (operasional).

\section{SIMPULAN}

Beranjak dari hasil penelitian dan analisa penulis terhadap Kinerja Aparatur Pemerintah Daerah Sekretariat Daerah Kabupaten Bolaang Mongondow Pasca Pemindahan Ibu Kota sebagaimana yang tertuang dalam BAB IV, maka dapat disimpulkan hal-hal sebagai berikut.

1. Kinerja aparatur permerintah daerah Kabupaten Bolaang Mongondow pasca pemindahan ibu kota dilihat dari berbagai dimensi yaitu kuantitas kerja, kualitas kerja, ketepatan waktu, kehadiran, dan kemamputan kerja sama, serta berbagai indikator yang menyertai memang mengalami penurunan yang cukup signifikan. Penelitian yang dikalakukan memberi pemahaman bagi peneliti (verstehen), bahwa pemindahan ibu kota yang dilakukan begitu terburuburu, tanpa mempertimbangkan dengan matang berbagai aspek teknis yang harus dilakukan sebelum pemindahan ibu kota.

2. Beberapa faktor pendukung dan penghambat peningkatan Kinerja Aparatur Pemerintah Daerah Sekretariat Daerah Kabupaten Bolaang Mongondow Pasca Pemindahan Ibu Kota adalah sebagai berikut.

\section{a. Faktor Pendukung}

Adanya Komitmen Pimpinan untuk meningkatkan Kinerja ASN, lahirnya Undang-Undang Nomor 5 Tahun 2014 tentang ASN berserta tutunanturunannya; tesedianya pendidikan lanjutan bagi ASN dari berbagai intansi publik atau swasta; telah tersedianya sarana angkutan bagi ASN yang tinggal di Kotamobagu, tersedianya rumah susun bagi ASN, adanya Program Pengolahan
Data yang memadai untuk pengelolaan surat di Sekretariat Daerah Kabupaten Bolaang Mongondow, adanya penerapan teknologi informasi pada tatanan manajemen pemerintahan di Kabupaten Bolaang Mongondow

\section{b. Faktor Penghambat}

Masih minimnya fasilitas penunjang pekerjaan di hampir semua bagian di Sekretariat Daerah, belum maksimalnya pengendalian dan pengawasan internal bagi aparatuur dan tindakan tegas bagi aparatur yang melanggar ketentuan disiplin, belum adanya reward and punishment system, minimnya TPP bagi ASN dan masih minumnya insentif bagi THL, faktor jarak tempat tinggal ASN, kondisi lingkungan kerja yang kurang nyaman (comfortable) bagi Aparatur Pemerintah di Sekretariat Daerah, Standar Operasional Prosedur yang belum dijadikan acuan dalam pelaksanaan pekerjaan.

3. Strategi perningkatan kinerja yang menjadi core dari penelitian ini berdasarkan pada analisis faktor internal (ability, strength, dan agility) dan eksternal (opportunities dan culture), terdapat 11 rumusan langkah strategis yaitu : pemanfaatan teknologi, peningkatan pendidikan bagi ASN, penegakan disiplin, memaksimalkan sarana hunian yang telah tersedia, melakukan penilaian terhadap seluruh ASN menyusul penempatan sesuai dengan hasil penilaian, memberikan pelatihan teknologi informasi, membangun sistem reward dan punishment, menerapkan tata kelola pemerintahan 4.0 secara bertahap dan berkesinambungan dalam rangka mewujudkan pemerintahan yang baik dan bersih (good governance), serta membangun kekompakan ASN dalam pelaksanaan tugas dan perannya masing-masing. 


\section{SARAN}

Merujuk pada hasil pembahasan dan kesimpulan, maka peneliti memberikan saran dalam rangka Penigkatan Kinerja Aparatur Pemerintah Daerah Sekretariat Daerah Kabupaten Bolaang Mongondow Pasca Pemindahan Ibu Kota sebagai berikut.

1. Dalam rangka meningkatkan Kinerja Aparatur Pemerintah Daerah Sekretariat Daerah Kabupaten Bolaang Mongondow pasca pemindahan Ibu Kota dapat dilakukan dengan:

a. Peningkatankuantitaskerjaaparatur Pemerintah di Sekretariat Daerah Kabupaten Bolaang Mongondow perlu terus diupayakan oleh Pemerintah Daerah. Diantaranya membangun sistem reward dan punishment serta melibatkan sampai pada tingakat pelaksana/staf untuk turut aktif dalam pembahasan perencanaan dan mempelajari dokumen-dokumen perencanaan seperti RPJMD, Renstra, dan Renja Pemerintah Daerah sampai pada Renstra dan Renja masing-masing unit kerja.

b. Peningkatan kualitas kerja aparatur Sekretariat Daerah Kabupaten Bolaang Mongondow perlu kirannya memperhatikan penerapan SOP dan meningkatkan anggaran pengadaan fasilitas kerja bagi aparatur serta pemberian diklat fungsional dalam rangka meningkatkan kapasitas aparatur.

c. Ketepatan waktu aparatur di Sekretariat Daerah dilakukan dengan memberikan sangsi tegas bagi ASN yang melakukan pemborosan waktu kerja.

d. Dalam rangka meningkatkan kehadiran aparatur perlu adanya pengawasan dan pengendalian internal bagi aparatur Pemerintah di Sekretariat Daerah, peningkatan insentif (TPP) ASN serta penegakan aturan yang mengatur disiplin ASN .

e. Dalam rangka meningkatkan kemampuan kerja sama ASN di sekretariat daerah perlu kiranya Moto Leluhur lebih dijadikan pedoman dalam membangun rasa kekompakan dan kebersamaan dari ASN di Sekretariat Daerah.

2. Bahwa dalam rangka mengatasi faktor penghambat dalam Peningkatan Kinerja Aparatur Permerintah Sekretariat Daerah Kabupaten Bolaang Mongondow pasca pemindahan Ibu Kota yaitu:

\section{a. Faktor Pendukung}

Fakor pendukung yang telah disebutkan peneliti agar senantiasa ditingakatkan, dipertahankan bahkan dimanfaatkan untuk Peningkatan Kinerja Aparatur Pemerintah di Sekretariat Daerah Kabupaten Bolaang Mongondow. Terutama komitmen bersama untuk meningkatkan kinerja, ketersediaan rumah susun bagi aparatur pemerintah daerah, serta memaksinalkan penggunaan teknologi informasi dalam pelaksanaan pekerjaan.

b. Faktor Penghambat

Faktor penghambat Peningkatan Kinerja Aparatur Pemerintah di Sekretariat Daerah kiranya perlu di atasi, terutama dalam hal komptensi ASN di Sekretariat Daerah, Reward and Punishment, perbaikan lingkungan kerja bagi pelaksana/staf, dan penerapan standar kerja yang telah dibuat bersama.

3. Strategi peningkatan kinerja dilakukan dengan membertimbangkan faktorfaktor internal maupun eksternal yaitu dengan pemanfaatan teknologi, peningkatan pendidikan bagi ASN, penegakan disiplin, memaksimalkan sarana hunian yang telah tersedia, 
melakukan penilaian terhadap seluruh ASN menyusul penempatan sesuai dengan hasil penilaian, memberikan pelatihan teknologi informasi, membangun sistem reward dan punishment, menerapkan tata kelola pemerintahan 4.0 secara bertahap dan berkesinambungan dalam rangka mewujudkan pemerintahan yang baik dan bersih (good governance), serta membangun kekompakan ASN dalam pelaksanaan tugas dan perannya masing-masing.

\section{DAFTAR PUSTAKA}

Bangun Wilson, 2012, Manajemen Sumber Daya Manusia, Penerbit Erlangga, Jakarta;

Bevir Mark, 2007, Encyclopedia of Government, Sage Publication, California;
C. F. Strong, 1960, Modern Political Constitusional, Sidgwick and Jackson, Ltd London;

Flipo, E.B. Personnal Management, Six Edition, Mc. Graw Hill. Inc;

General Secretary of OECD, 2008, The State of Public Service;

Heene Aimi et al., 2010, Manajemen Strategik Keorganisasian Publik, PT. Refika Adiatma, Bandung

Mitchell R. Terence, 1987, People in Organization An Introduction to Organizational Behavior, International Student Edition, MC. Graw Hill Kogakhusa, Ltd;

Suradinata Ermaya, 2014, Analisis Kepemimpinan Strategi Pengambilan Keputusan, Jatinangor, Alqaprint;

https://kbbi.kemdikbud.go.id/entri/kinerja

https://kbbi.kemdikbud.go.id/entri/tepat 